\title{
Enhancement of shelf life of paneer by surface salt treatment
}

\author{
HK Malodia and BS Beniwal
}

Received: 15 March 2019 / Accepted: 12 June 2019 / Published online: 22 June 2019

(c) Indian Dairy Association (India) 2019

\begin{abstract}
Paneer was prepared and cut into cubes of three sizes i.e. $1.5,2.5$ and $3.5 \mathrm{~cm}$. Their surfaces were treated with two concentrations $(0.8$ and $1.2 \% \mathrm{w} / \mathrm{w}$ basis $)$ of dry common salt. They were packed in LDPE (50-55 micron) packages and stored at 3 different temperatures i.e. $20 \pm 2^{\circ} \mathrm{C}, 5 \pm 2^{\circ} \mathrm{C}$ and $-15 \pm 2^{\circ} \mathrm{C}$. The paneer cubes of $2.5 \mathrm{~cm}$ size served as control. It was revealed that the paneer cube of $1.5 \mathrm{~cm}$ cube size with $1.2 \%$ salt application had the longest shelf life as evidenced by the sensory scores; supported by lower TBA, FFA and NPN values. Paneer cubes of $1.5 \mathrm{~cm}$ size had a score above "like slightly" even on the tenth day of storage at $5^{\circ} \mathrm{C}$. All the samples stored at $-15^{\circ} \mathrm{C}$ were acceptable on $60^{\text {th }}$ day; however, paneer cubes of $1.5 \mathrm{~cm}$ size and $1.2 \%$ salt scored high on the sensory scale.
\end{abstract}

Keywords: FFA, NPN, Paneer, Shelf life, Salt application, TBA

\section{Introduction}

Out of the total milk produced in India $46 \%$ is consumed as liquid milk and rest of the milk is converted into milk products like ghee/ makhan (33\%), khoa (7\%), Dahi (7\%) (3\%) and milk powder etc. (4\%) (Aneja et al. 2002). The total paneer production in the country per year is about 0.2 MT (Aneja et at., 2002). Paneer is a heat and acid coagulated milk product which is either consumed as raw or is used in preparation of various types of curries. Like other traditional milk products of India, paneer also has a limited shelf life. With the application of existing techniques employed for the production and packaging, it is only one day at ambient temp and about one week at refrigerated temperature (Bhattacharya et al. 1971; Vishweswaraiah and Anantakrishnan, 1985). Various workers have made efforts to enhance the shelf life of paneer through different methods like vacuum packaging, using brine, hurdle technology and bio-preservatives etc.

Singh et al. (1988) dipped paneer blocks of $1.5 \mathrm{~kg}$ each in $5 \%$ brine, chilled water and acidified water ( $\mathrm{pH}$ 5.0) to enhance its shelf life (up to 12 days at refrigeration temperature). Singh et al. (1989) found that addition of $0.15 \%$ sorbic acid to milk for paneer preparation or wrapping the paneer in sorbic acid coated butter paper $\left(2 \mathrm{gm} / \mathrm{m}^{2}\right)$ extended its shelf life to 30 days at ambient temperature. Hot $\left(60{ }^{\circ} \mathrm{C}\right.$ for $\left.5 \mathrm{~min}\right)$ and cold $\left(8-10^{\circ} \mathrm{C}\right.$ for $\left.6 \mathrm{~h}\right)$ diffusion of paneer cubes with sodium chloride and potassium sorbate and subsequent microwave drying was done by Singh and Rai (2004) to extend its shelf life. Kumar and Puranik (2011) found that the paneer samples treated with $20 \mathrm{ppm}$ lactoferrin had significantly lower microbial growth. Surface application of crude bacteriocin produced by Enterococcus faecium BS 13 extended the shelf life of paneer up to 15 days under refrigeration conditions (Vandana et al. 2013)

Surface of the paneer exposed to environment is most vulnerable to microbial growths which produce slime and undesirable sensory changes and thus spoilage starts. In view of the above the present study was planned to extend the shelf life of paneer by surface application of common salt to paneer cubes, which is supposed to reduce the surface water activity and hence microbial growth also. 


\section{Materials and methods}

\section{Procurement of raw materials}

Buffalo milk was procured form the Experimental Dairy of CCS Haryana Agricultural University, Hisar. Commercial grade fine salt of M/s Tata Chemicals, Mumbai was used. A.R. Grade chemicals were used for chemical analysis

\section{Manufacture of paneer}

Paneer was prepared as per the method suggested by Sachdeva and Singh (1988). The fat content of milk was determined by the Gerber method as per BIS (1989). Buffalo milk was standardized to 5.8 per cent fat using fresh buffalo skim milk. The milk was heated to $90^{\circ} \mathrm{C}$ without holding. The temperature of milk was brought down to $70^{\circ} \mathrm{C}$ and was coagulated at this temperature using 1 per cent citric acid solution maintained at $70^{\circ} \mathrm{C}$. Citric acid solution was added with continuous agitation till clear whey separated out. After complete coagulation, the whey was drained through muslin cloth and curd was filled in hoops lined with strong and cleaned muslin cloth. Pressure was applied on the hoops for 10 min by putting weight equal to weight of milk taken. The pressed block of curd was removed from the hoop, cut into pieces and immersed into chilled water for an hour.

\section{Packaging}

The chilled blocks of paneer were then removed from the water and placed on wooden planks for 10-15 min to allow loose water to drain and then paneer blocks were wiped with sterilized towel. In one set of experiment the paneer was cut into 1.5, 2.5 and 3.5 $\mathrm{cm}$ cube sizes and packaged in LDPE (50-55 micron) packages. In second set of experiment the paneer was cut into 1.5, 2.5 and 3.5 $\mathrm{cm}$ cube sizes and their surface was treated with 0.8 and $1.2 \%$ (w/ w) dry salt and packaged in LDPE (50-55 micron) packages. The paneer cubes of $2.5 \mathrm{~cm}$ packed in LDPE (50-55 micron) served as control. These paneer packages were stored at 3 different temperatures i.e. $20 \pm 2^{\circ} \mathrm{C}, 5 \pm 2^{\circ} \mathrm{C}$, and $-15 \pm 2^{\circ} \mathrm{C}$.

\section{Sensory evaluation}

The paneer samples were evaluated organoleptically for different quality attributes like Flavor (F), Body \& Texture (BT), Color \& Appearance (CA) and Overall Acceptability (OA) by a

Table 1 Proximate composition of paneer

\begin{tabular}{lc}
\hline Constituents & Percent \\
\hline Moisture & $57.4 \pm 0.64$ \\
Fat & $22.5 \pm 0.31$ \\
Protein & $17.1 \pm 0.38$ \\
Lactose & $2.4 \pm 0.04$ \\
Ash & $1.6 \pm 0.02$ \\
\hline
\end{tabular}

Values are mean \pm S.D. of 3 replications panel of six judges using 9 point Hedonic scale which is given below.

$\begin{array}{lr}\text { Response } & \text { Score } \\ \text { Like extremely } & 9 \\ \text { Like very much } & 8 \\ \text { Like Moderately } & 7 \\ \text { Like Slightly } & 6 \\ \text { Neither Like nor Dislike } & 5 \\ \text { Dislike Slightly } & 4 \\ \text { Dislike Moderately } & 3 \\ \text { Dislike Very Much } & 2 \\ \text { Dislike Extremely } & 1\end{array}$

\section{Chemical examination of paneer}

Various chemical parameters analyzed for fresh and stored paneer are as Moisture (IS: 10484 -1983), Fat (IS: 4079-1967), Total Protein (BIS, 1989), Non-protein nitrogen (Rowland, 1938), Lactose (BIS, 1989), Ash (BIS, 1989), Thiobarbituric acid (Strange et al. 1977), Free fatty acids (Koniecko, 1979). The data obtained during the present investigation were suitably analyzed by employing statistical designs (Snedecor and Cochran, 1967).

\section{Results and discussion}

Proximate composition of paneer that was produced for the study is presented in Table - 1. The composition of paneer is almost similar to the composition as reported by Bhattacharya et al. (1971) and Singh and Kanawjia (1988).

\section{Sensory Attributes of paneer samples}

\section{Effect of size of cube and salt concentration on Sensory Attributes of paneer stored at $20^{\circ} \mathrm{C}$ and $5^{\circ} \mathrm{C}$}

On zero day of storage the Flavor and Overall Acceptability of Paneer cubes $(1.5 \mathrm{~cm})$ treated with 1.2 percent salt were significantly higher in comparison to the control samples and other samples of 2.5 and $3.5 \mathrm{~cm}$ size (Table 2). It reveals that surface salt treatment/application at the rate of 1.2 percent to smaller cubes of $1.5 \mathrm{~cm}$ size enhances flavor of paneer. This is general practice also to eat salt applied paneer for flavor enhancement. Salt at 0.8 percent did not produce any significant effect on sensory scores of paneer cubes of any size.

On the second day of storage at $20^{\circ} \mathrm{C}$, acceptance of cubes had decreased drastically for flavor and overall acceptability. Formation of greenish yellow slime on the surface of the paneer and development of rancid off smell was observed in most of the samples. However, no slime was observed in the $1.5 \mathrm{~cm}$ cubes treated with 0.8 and 1.2 percent salt. The score for flavor and overall acceptability of these samples were significantly higher in comparison to other cube sizes. Significant difference was noted due to size of the cube and level of salt treatment. 
Samples stored at $5^{\circ} \mathrm{C}$ had good acceptability on $5^{\text {th }}$ day while on $10^{\text {th }}$ day most of the samples had surface growth of yeast and mold and greenish yellow slime emitting off smell. The decrease in sensory scores during storage was found to be significant. Size of paneer cubes and level of salt had a significant effect on sensory scores.

On the second day storage at $20^{\circ} \mathrm{C}$, the most acceptable samples were of $1.5 \mathrm{~cm}$ cube size with $1.2 \%$ salt concentration. The same was also true for storage at $5^{\circ} \mathrm{C}$ on $5^{\text {th }}$ day.. This may be because of inhibitive effect of salt on proteolytic and other undesirable organisms and also by reducing water activity. The effect of salt concentration on flavour was also significant.

\section{Effect of size of cube and salt concentration on Sensory Attributes of paneer stored at $-15^{\circ} \mathrm{C}$}

There was no effect of size of cube or salt treatment up to 15 th day of storage on any of the sensory attribute (Table-3). Size of cube or salt treatment did not have any effect up to $30^{\text {th }}$ day of storage on Color and Appearance, Flavor and Overall
Acceptability of the paneer samples. However, the Body and Texture scores were lower with storage. From the scores of the sensory attributes it can be inferred that paneer can be successfully stored up to 30 days at $-15^{\circ} \mathrm{C}$ as all the scores are above 7 (Like moderately). On $45^{\text {th }}$ day no effect of cube size or salt concentration was observed on Color and Appearance, Body and Texture and Flavor on the samples which were treated with $1.2 \%$ salt and were of $1.5 \mathrm{~cm}$ cube size. In other samples the sensory scores decreased. On 60th day of storage although the sensory scores were less but still they were higher in comparison to the control sample to a significant level except for body and texture and color and appearance. The reduction in color and appearance may be due to the adverse effect of freezing and thawing which destroyed the surface of paneer. The reduction in body and texture scores may be due to the formation of ice crystals in the samples which in turn damage the casein matrix. The experimental samples were better than the control which indicates that the salt treatment has improving effect on the paneer. Even though all the samples were acceptable at the end of storage i.e. on 60 th day but paneer cubes of $1.5 \mathrm{~cm}$ size and $1.2 \%$ salt were

Table 2 Effect of size of cube and salt conc. on Sensory Attributes of paneer during storage at $20^{\circ} \mathrm{C}$ and $5^{\circ} \mathrm{C}$

Treatment

Sensory Score

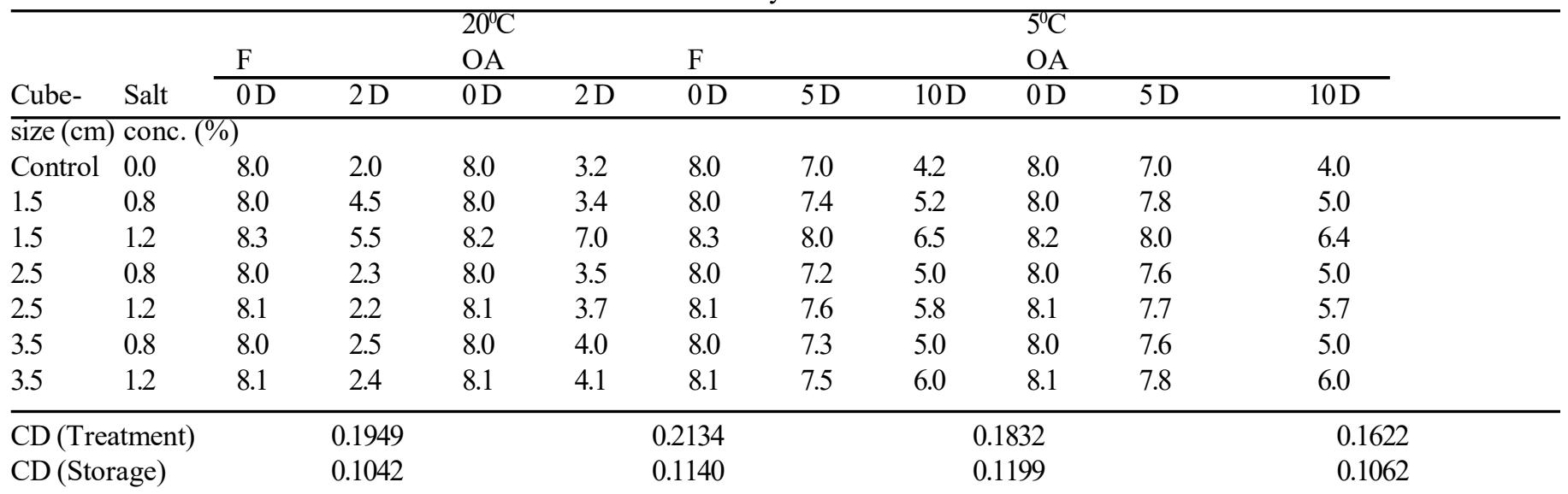

Table 3 Effect of size of cube and salt conc. on sensory scores of paneer during storage at $-15^{\circ} \mathrm{C}$

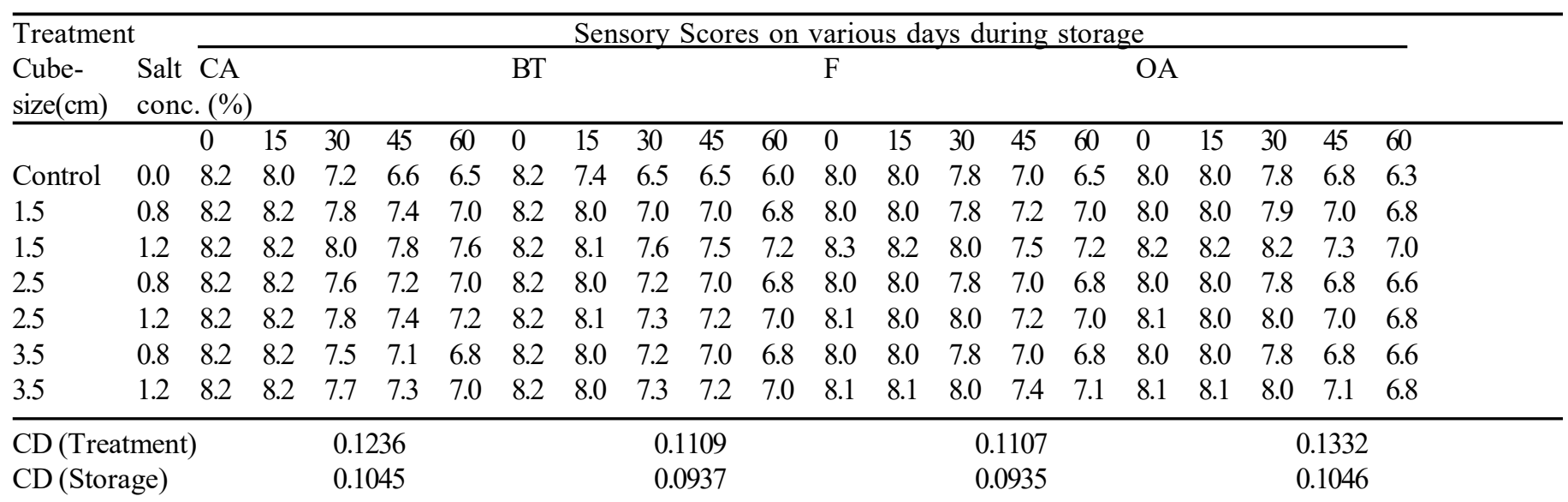


Table 4 Effect of size of cube and salt treatment on TBA (mg mal/1000g), Free Fatty acid (\%) and NPN (\%) of paneer during storage at $20^{\circ} \mathrm{C}$ and $5^{\circ} \mathrm{C}$

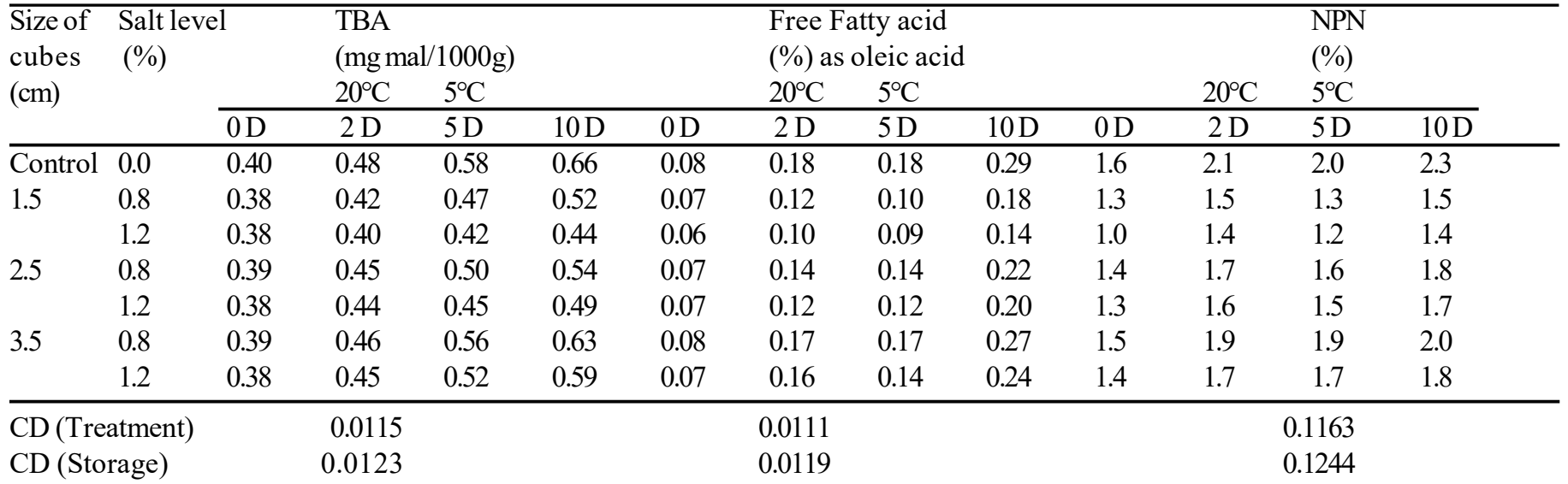

Table 5 Effect of size of cubes and salt treatments on TBA (mg mal/1000g), Free Fatty acid (\%) and NPN (\%) of paneer during storage at $-15^{\circ} \mathrm{C}$

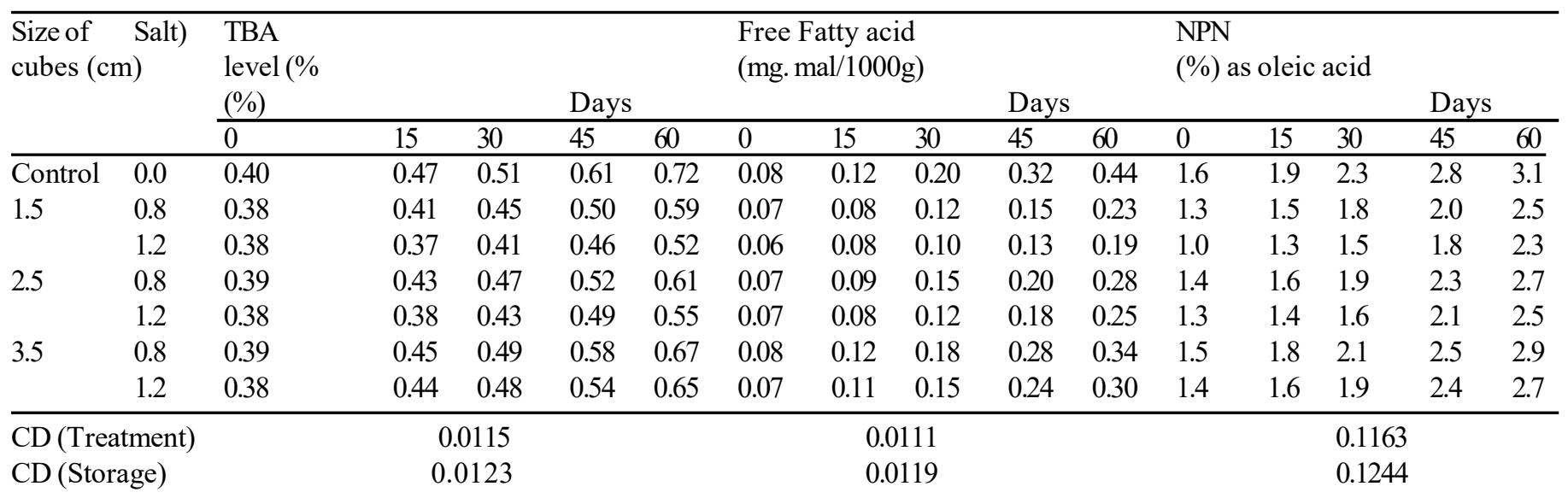

preferred throughout the storage, scoring high on the sensory scale.

\section{Chemical characteristics of paneer during storage}

In support of sensory characteristics, chemical characteristics were also analyzed for all the samples i.e. Thiobarbituric Acid (TBA), Free Fatty Acid (FFA) and Non-Protein Nitrogen (NPN).

\section{Effect of size of cubes and salt treatment on chemical characteristics of paneer during storage at $20^{\circ} \mathrm{C}$ and $5^{\circ} \mathrm{C}$.}

As can be seen in Table-4, during storage of paneer cubes at $20^{\circ} \mathrm{C}$ and $5{ }^{\circ} \mathrm{C}$, TBA value increased for all samples and was positively related with the size of cubes. The levels of salt treatments were inversely related with TBA values of paneer. The FFA values also had similar trend as TBA. The maximum increase was observed in control samples while minimum in 1.5 $\mathrm{cm}$ cube size paneer treated with $1.2 \%$ salt. Values of FFA indicate that salt had inhibitory effect on lipolysis of fat in paneer. In bigger cubes of paneer salt might not have reached to the centre of the cube and thus there was no protective effect of salt and hence the increase in FFA content was more in such paneer samples. NPN is an indicator of proteolysis taking place in milk products. NPN values indicate that some degree of proteolysis had taken place in all paneer samples. The size of cubes had positive relationship with NPN values while level of salt had inverse. The size of paneer cubes, level of salt treatments, storage temperatures and duration had significant effect on the chemical characteristics of the paneer in terms of TBA, FFA and NPN.

\section{Effect of size of cubes and salt treatment on chemical characteristics of paneer during storage at $-15^{\circ} \mathrm{C}$}

During storage at $-15^{\circ} \mathrm{C}$, the effect of size of the cubes and salt treatment on chemical characteristics of paneer was similar to the effect on storage at $20^{\circ} \mathrm{C}$ and $5^{\circ} \mathrm{C}$ as is evident in Table-5. The storage temperature $-15^{\circ} \mathrm{C}$ showed direct effect on chemical parameters as it slowed down the rate of reaction during the length of storage in comparison to storage at $20^{\circ} \mathrm{C}$ and $5^{\circ} \mathrm{C}$. 
The values of TBA, FFA and NPN had positive relationship with size of cubes of paneer while level of salt had an inverse relationship with these during storage. It is evident from table that values of all three chemical parameters were maximum in control and minimum in $1.5 \mathrm{~cm}$ cube size paneer treated with 1.2 percent salt.

\section{Conclusions}

On addition of $1.2 \%$ salt the paneer cubes of $1.5 \mathrm{~cm}$ size was acceptable upto $2^{\text {nd }}$ day and $5^{\text {th }}$ day at $20^{\circ} \mathrm{C}$ and $5^{\circ} \mathrm{C}$ respectively in terms of sensory parameters. Salt at 0.8 percent did not produce any significant effect on sensory scores of paneer cubes of any size. Size of cube or salt treatment did not have any effect up to $30^{\text {th }}$ day of storage on Color and Appearance, Flavor and Overall Acceptability of the paneer samples at $-15^{\circ} \mathrm{C}$. In terms of chemical parameters, the FFA, TBA and NPN value increased in all the samples; however, the maximum increase was observed in control samples while minimum in $1.5 \mathrm{~cm}$ cube size paneer treated with $1.2 \%$ salt.

\section{References}

Aneja RP, Mathur BN, Chandan RC, Banerjee AK (2002) Heat-acid coagulated products. In Technology of Indian milk product, Dairy India Yearbook, A Dairy India Publication, New Delhi, p 133-142

Bhattacharya DC, Mathur ON, Srinivasan MR, Samlik O (1971) Studies on the methods of production and shelf life of paneer. J Food Sci Technol 8: 117-120
BIS (1989) Methods of analysis of milk and milk products. Indian Standards Institute (BIS), Manak Bhavan, New Delhi

IS 10484 -1983. Specification for paneer. Bureau of Indian Standards, New Delhi

IS: 4079-1967. Analysis of Milk and Milk Products. Indian Standards Institution, Manak Bhavan, New Delhi

Koniecko ES (1979) Handbook, of meat chemistry. Avery Publishing Group, Inc. Wayne, New Jersey, pp. 53-55

Rowland SJ (1938) The heat denaturation of albumin and globulin in milk. Dairy Sci 9(1):42-46

Sachdeva S, Singh S (1988) Optimization of processing parameters in the manufacture of paneer. Food Sci Technol 25(3):142-145

Shashikumar CSS, Puranik DB (2011) Study on use of Lactoferrin for the biopreservation of paneer. Tropical Agric Res 23: 70-76

Singh L, Mohan MS, Puttilingamma V, Sankaran R (1989) Preservation of paneer by sorbic acid. J Food Sci Technol 26:129-132

Singh S, Kanawjia SK (1988) Development of manufacturing technique of paneer from cow milk. Indian J Dairy Sci 41: 322

Singh S, Rai T (2004) Process optimization for diffusion process and microwave drying of paneer. J Food Sci Tchnol 41: 487-491

Singh S, Kanawjia SK Sachdeva S (1988) Extension of shelf life of paneer. Asian J Dairy Sci Res 7:147-151

Snedecor GW, Cochran WG (1967) Statistical methods. 6th ed. The Iowa State College Press, Ames, Iowa

Strange ED, Benedict RC, Smith JL, Swift CE (1977) Evaluation of rapid tests for monitoring alternating in meat quality during storage. $\mathrm{F}$ Food Prot 40: 843

Vandana B, Panesar PS, Bera MB (2013) effect of bacteriocin extracted from Enterococcus faecium BS 13 on shelf life of paneer and khoya. Int J Food Nutr Sci 2: 5-11

Vishweshwaraiah L, Anatakrishnan CP (1985) A study on technological aspects of preparing paneer from cow milk. Asian J Dairy Sci 4: $171-176$ 